\title{
The Union of South Africa Propaganda Campaigns during the World War II
}

\author{
By Anli Le Roux
}

Fall 2012 Issue of KINEMA

\section{THE UNION OF SOUTH AFRICA PROPAGANDA CAMPAIGNS DURING THE SECOND WORLD WAR (1939-1945).}

\section{Part 1: The African Mirror Newsreels}

\section{Introduction}

According to Danny Schechter, when one fights a war, "there is a need to create and maintain ties of sentiment between soldiers and citizens, as well as a need for popular mobilisation and media support" (2004:25). During the Second World War the case was no different in South Africa. The Union of South Africa propaganda campaigns in all its forms were aimed at "motivating, managing, and feeding the media" which in turn fed the nation. This was a key strategic imperative to try to build, strengthen and maintain a consensus and united front behind the war effort (Schechter, 2004:25). The significance of contemporary filmic visualisation or off-screen enactments of war experiences and their place in South African historiography of the Second World War has long been an under-researched area.

Already during the Second Anglo-Boer War (1899-1902), those involved in the war were aware of the vital importance of having well-established information-spreading systems of a propagandistic nature in place. Although the aims and methods of propaganda campaigns would have differed greatly form those deployed by the Union government during the Second World War, it is still clear that the ground broken between 1899 and 1902 ensured that the propaganda campaigns of 1939-1945 could get out of their starting blocks with more efficiency.

During the inter-war years, as well as after South Africa had declared war against Germany, there were two important film production companies: the African Films Trust established in 1913 by Isadore Schlesinger. This company was responsible for the creation of the African Mirror Newsreels in that same year which is considered to be the first documentary vehicle of its kind in South Africa. From its inception, the company operated closely with the state in its production of fictional, documentary and historical films which, during the war year of 1939-1945, functioned as leading agents of propaganda and "war education."

By the outbreak of the war in 1939, an offshoot of African Films Trust, the African Film Corporation, was producing official propaganda films for the authorities. For example, the Afrikaans film Noordwaarts was produced for the Union Unity Truth Service. However, by the late 1930s the African Film Corporation which had dominated the industry prior to the build-up to the war, was now starting to experience a loss of profits as a result of the expanding Union Film Productions (Chetty, 2006:56).

It was then essential for South African war propagandists to reflect on and consider the real needs and desires of the audience, especially the marginalized and disempowered sectors of society. They also needed to deliberate on the possibilities of shifts or challenges to the prevailing social order which could arise as a result of the propaganda and its reception by the audience. These factors that came into play in the Union after the declaration of war made the earlier 1940s a key moment in the country's twentieth-century history where marginalized groups had the potential to contest their social position, in particular in terms of race and gender (Chetty, 2006:52).

From the outset of the Union's entry into the war, the stage was set not only for a physical battle to be fought on the battlefield or off the coast away from home, but for the imminent fighting of another type of battle - one to be fought for in the hearts and minds of South Africans. Along with print, the pro-war visual media broadcasts in South Africa between 1939-1945 was significant in that it sought to carry a created sense of the war back to the homes of South Africans, particularly those without a newspaper or magazine reading custom. There, they expressed aspects of the country's Second World War experience that served serious propaganda intent. 
As a propaganda tool, the effect of the African Mirror newsreels in particular, appears to have been farreaching and more politically directed in its goal than a mere source of local entertainment or war-escapism. The African Mirror newsreels, as well as other short films (to be discussed in Part 2) were aimed at influencing the opinions and attitudes of the Union's people. It aimed to inform South Africans of the country's war policy and efforts and ultimately to get as much support for the war efforts as possible.

The British historian, David Welch, wrote that during the Second World War newsreels "increasingly became a formalistic, carefully planned artistic transformation of reality in an attempt to achieve the propaganda intentions" (Welch, 2001:164). In South Africa the African Mirror Newsreels ultimately determined and shaped the image of the Union both within its own borders and in an international arena. The newsreels screened from 1939-1945 succeeded in bringing the war to the homes of Union citizens. Although the extent to which propaganda influenced or shaped actual perceptions of the progress of wartime affairs is not necessarily easy to judge in any definitive way, this study will examine both the formation and role of these screen depictions - both as wartime information source and as a national propaganda effort of the pro-war Union government in the context of major internal division over the war effort.

\section{Background to the Conflict}

When one is trying to put the Second World War into a global, and in particular, into a South African frame of reference, one has to paint an intricate picture of political, economic and social colours against the backdrop of the preceding war years of 1914-1918. The Treaty of Versailles, signed at the Paris Peace Conference in 1919, which ushered in the era between the two World Wars, set the table of world politics in such a way that ensured that World War II would turn out to be a very different affair altogether. A total reordering of the globe was at stake, and South Africa with its enormous mineral wealth and agricultural assets would feature inevitably in any power struggle involving a rising Germany and its adversarial British Empire.

General Jan Smuts, the country's key national figure in the wartime 1940s, combined a position of explicit internationalism with a commitment to the national affairs of South Africa. The first post-1918 Smuts government found itself walking on an unavoidable tightrope between Afrikaner nationalists and Englishspeaking whites - consequently it had to consistently emphasize both the cooperation with the British imperial order and a strong interpretation of South Africa's status as an increasingly independent loyal Dominion.

The attitudes, grievances and anxieties harboured by the majority of the Union's white citizens about the decision to side with Britain in 1939 had its roots in the Afrikaner past which culminated in the devastation of the Second Anglo-Boer War, fought from 1899-1902. In the aftermath of this war, the Afrikaners perceived their history as a bitter struggle for self-preservation and self-determination against the British. Grundlingh notes that "at the outbreak of the war, Smuts had to tread wearily not to antagonize and inflame the sentiments of Afrikaners in the anti-war camp" (1999:354). Mindful of these concerns and of the divisions in the Union's white society, Smuts decided against conscription and relied exclusively on volunteers to fill the ranks of the defence force which was badly understaffed at the outbreak of the hostilities.

The Union Defence Force (UDF) consequently embarked on an intensive and multi-faceted (white) propaganda campaign to win the hearts and minds of people and build trustworthiness, especially with neutral and anti-war groups. Ultimately, a close relationship between the awakening of a vibrant Afrikaner consciousness and the development of a useable contemporary historical consciousness ensued. During the period 1939-1945, however, the Afrikaner use of the past was primarily a functional one, and it served many well as they sought to maintain their identity and independent interests in the face of the British culture. The main thrust of recruiting (and propaganda campaigns) was clearly to link the war to Afrikaner history, politics and culture. This stance at the time of South Africa's entry into the war presented the government and its UDF propaganda enterprise with a challenging gateway through which to channel campaigns to win support for the war effort.

\section{Definitions of Propaganda}

By the end of 1939, national cinemas worldwide were adapting and expanding their role and influence from the initial aims of providing mass entertainment to acting as a source of controlled information on the war. At this level, cinema came to play a pivotal role in reshaping the views and sentiments of audiences affected 
by the war, as it projected itself as an informative medium. Films were the blank canvases onto which the colours of a current (and ongoing) wartime experience could be projected. For those citizens at the home front, the films screened during the Second World War succeeded in giving meaning to events. Due to the psychological and emotional levels of the human psyche, these films tapped into, and acted as a popular form of mass communication as hostilities progressed.

Butcher notes Welch's argument are two common misconceptions concerning the study of propaganda. First, it is pointed out that certain types and forms of propaganda "implies nothing less than the art of persuasion, which serves only to change attitudes and ideas" (Butcher, 2002:2). This is irrefutably one of its core purposes, but is commonly more limited and partial in its scope of reach. Propaganda is more often concerned with reinforcing existing trends and beliefs, to sharpen and focus them. Secondly, it is pointed out that it is careless, when discussing the complex phenomenon of propaganda, to assume that serious or persuasive "propaganda" is grounded entirely on deceits or falsehoods. Its viewers, readers and listeners are instead urged to acknowledge and to constantly be aware of the fact that propaganda "operates with many different kinds of truth - from the outright lie, the half-truth, to the truth out of context" (Butcher, 2002:2).

The Nazi propaganda leader Joseph Goebbels strongly believed that the main purpose of propaganda is to "achieve acceptance of the propagandist's ideologies by the people", and that there is no fundamental method to propaganda, but only a purpose - "the conquest of the masses" (Doherty, 2000:3). In other words, successful propaganda relates to, and builds up its arsenal, form the prevailing mood of the times, and understanding the climate of the time is therefore crucial to the effectiveness of any propaganda effort.

In their discussion on propaganda and mass persuasion, Nicholas Cull and co-authors draw heavily on a perceived distinction between "black and white propaganda" (Cull \& Cullbert et al., 2003:41-42, 425-426). With white propaganda, by its definition, not only the source(s) of the information are known, but the aims and intentions were clearly identified, and the public knew that an effort was being made to influence its beliefs and thinking. On the other hand, black propaganda (also referred to as "covert propaganda") constantly aims to conceal its own identity by alleging that it originates from a secondary source or place that the true source. It is thus regarded as a "deliberate distortion with the source being concealed and/or inaccurate" (Cull \& Cullbert et al., 2003:41-42, 425-426).

White propaganda intends to convince an audience of the authority and justness of a particular establishment or ideology - it is thus used to build credibility with the target audience, as this could prove to be useful at some point in the future. With black propaganda, in turn, sources are most probably an institution, organization, group or individual - it thus seeks to mislead and encompass all styles and forms of creative deception which ranges from leaflets, posters, radio and television programmes.

From the outset of the Second World War, national cinemas gained momentum and the popularity of films increased greatly amongst audiences of countries involved in the conflict. As already suggested - films produced during the war years were not merely a form of escapism, but were deployed rather as informational tools and carriers of ideology by die combatant nations attempting to shape their citizens' thoughts and sentiments towards the war effort. Films and newsreels, such as the African Mirror newsreels, were carefully crafted and scripted in order to try to ensure that they had a strong impact on viewers. This meant that they had to convey a clear, simple message, and had to be short. The primary aim of wartime short films was to "put across essential information in a swift and easily digested form, thereby allowing people to remember government messages by putting them in dramatic form" (Spicer, 1992:105-106).

Provided that these short films and newsreels could be produced and distributed swiftly, it would ensure that they would retain a necessary contemporaneity and newsworthiness. Kenneth Clark, Head of the Films Division in 1940, however, had more ambitious hopes - he argued that "people's minds had to be seriously occupied, to be extended, as it were, for a short time every day", and for that reason these short films could be both instructional and encouraging (Spicer, 1992:105-106). This would help, it was argued, to empower people to comprehend the scope and complexity of the war effort and their role in it as responsible and well-informed citizens and servicemen and servicewomen.

Jowett and O'Donnell argue that when the use of propaganda is associated with an institutional purpose, it will then necessarily be linked to notions of control and will represent an explicit attempt to alter or maintain 
a power balance that is advantageous to the propagandist. Thus, that "deliberate attempt is linked to a clear institutional ideology and objective [and] the purpose of propaganda is to send out an ideology to an audience with a related objective" (Jowett \& O'Donnell, 1999:3). In the case of South Africa, the Smuts government was attempting to instil a wave of patriotism - especially in Afrikaner communities - to support the war effort. This was done through endeavours which sought ultimately to reinforce, or to modify, the attitudes or behaviour of audiences.

Wartime posters, films and newsreels could be divided into different categories with regard to the function that they had to fulfil: a) those appealing to patriotism, b) those appealing to national security and recruitment, c) those campaigning for war production, d) those illustrating military and diplomatic developments of the war, e) those depicting the war atrocities of the enemy, and f) those appealing for support for homecoming servicemen (Sinclair, 1992:ii). The African Mirror newsreels, and other short films such as Oproep!, She is South Africa, and March to Victory, were productions that were carefully scripted, documented and aired in order to appeal to these notions.

\section{Union Propaganda Efforts and the African Mirror Newsreels}

The African Mirror, which dates back to 1913, acquired sound in July 1939, played a crucial role during the Second World War in South Africa. Along with other forms of visual propaganda, it sought to intensify the struggle to strengthen the standing of loyal Afrikaner nationhood, and this in turn motivated the movement to produce culturally specific campaigns - especially Afrikaans-language programs and films like those by the pioneer of South African cinema Joseph Albrecht. The films and newsreels produced by entities such as the Reddingsdaadbond Amateur Rolprent Organisasie (RARO) and the South African National Film Board, established in 1940 and 1942 respectively, tried to ensure that the Union's war effort remained on the lips and minds of the South African general public. Consequently, it can be argued that Second World War films produced and released during the war and thereafter, did not simply deal with the stories of men and women on the battlefield or on the home-front. They also explored the effects that the war had on personal relationships, thoughts and the emotional connection to notions of identity, nation and unity. Thus, the African Mirror newsreels and short films had a pivotal role to play in the ways in which viewers experienced and related to what was put on screen.

In addition to these visual productions, the UDF released numerous Military Propaganda Handbooks which were intended to have a limited circulation and had to be confined to the particular officer in each unit entrusted with the task of looking after the moral welfare of the personnel of the unit. The authors of these booklets acknowledged the fact that "propaganda ceases to be effective when the publication of official communiqués of carefully controlled articles written round these communiqués are the only war news allowed. An intelligent public demands more than the meagre official information served up with enthusiastic accounts of war events" (Military Propaganda Handbook No. 1, 1941:5). This insight into the inner workings of wartime propaganda later also helped the UDF in the production and screening of both informative newsreels and other short films during the war.

Through these booklets the UDF made its approach to the application of wartime propaganda within the Union abundantly clear. It was to emphasize the credibility of portraying "sober" truths against the "glitter" of assertions of the enemy cause. What mattered was belief in the superior accuracy of one over the other.

The following quotation is taken from the first section of the Military Propaganda Handbook No. 1:

The mistake should not be made of underestimating the cunning and ingenuity of the enemy. At the same time it is a serious mistake to overestimate it. Those who are responsible for propaganda among our own troops have very big advantage over the enemy in that truth is our ally and the glamour and artificial appeal of the Nazi and Fascist systems have been built on falsity (Military Propaganda Handbook No. 1, 1941:5)

What underpins this is, of course, acknowledging the distinction between different communicators, and of pointing out that an informative communicator has a unique aim of creating and upholding a "mutual understanding of concepts that are considered to be indisputable, and ideas that are based on facts." According to this rationale, Jowett and O'Donnell argue that propaganda uses informational communication in a similar fashion, with the only difference being that the core purpose exceeds the notion of mutual understanding. 
From this premise, propaganda is used to promote either a partisan or competitive cause that serves the best interest of the propagandist(s), but not necessarily in the best interest of the recipient(s) and the recipient(s) may consider the propaganda to be merely informative. There exists, as has been noted earlier in this study, a very fine line between white propaganda and informative communication, and as Jowett and O'Donnell point out, it is possible for these two to cross-cut and to intersect in times of war. Thus, from what can be deduced from the Union's propaganda campaigns, it becomes clear that the seemingly informative communications systems put in place can be linked to practices of white propaganda.

That media coverage serves a vital role in informing peoples during war time is an undeniable certainty, but the specific medium, content and subsequent distribution of such reports determines its reach in societies embattled in war. Here, Stella Bruzzi draws a crucial distinction between "newsreels" and "documentary." She states that "whilst the newsreel is limited to showing events, it is the function of the documentary to provide structure and meaning. A documentary, a structured and non-fiction film, does not aspire to convey in as pure a way as possible the real material at its core because this is what the newsreel [does]" (Bruzzi, 2006: 27).

The African Mirror newsreels, as well as the short films discussed in part two of this article, that were screened in South Africa during the war, functioned both visually and verbally as works of sociological propaganda.

This was particularly apparent in the case of propaganda programmes that were aimed at Afrikaner women. According to Chetty, these newsreels and short films had to make three major shifts during the course of the war. Firstly, these campaigns were aimed at recruiting women by portraying war work within the context of dominant prevailing thoughts on the "proper" role of women in Afrikaner society (2006:48). Secondly, attempts were made to stimulate wartime recruitment by tailoring propaganda in ways that highlighted the excitement and allure of war services (Chetty, 2006:48). Then, during the closing phases of the war, propaganda had to work to contain the "empowerment brought about by women's war-time work in order to return them to lives of domesticity" (Chetty, 2006:48). The "factual" tone of these visual messages and broadcasts was also reflected more widely in the slant of war propaganda productions.

In addition to the abovementioned distinctions, there were

[t]hree forms of visual propaganda which was aimed at both military and civilian audiences. The first is that of recruiting and information films created by the UDF; secondly there are the international films which were shown along with newsreels where cinema-going audiences would watch these newsreels before the feature film. And lastly, the third form is concerned till photographs which have similar origins to that of newsreels (Chetty, 2006:47).

Although the more embedded patriotic messages of the Union's newsreels did not change much, new images of marching out parades, progress in munitions-factories and the troops advancing on the front lines, were constantly monitored, filmed, and screened to South African audiences. The addition of music and commentary attempted to increase the propagandistic value of the African Mirror newsreels - at times making up for the power that their images may have been lacking to convey. Here, the African Mirror newsreels functioned as a form of domestic propaganda, operating as part of a civil public information campaign which was designed to maintain military authority during the war years.

Sections of the E. G Malherbe Collection, Films for Training and Films for Publicity and Propaganda, reveal that the Film Unit, which was set up in 1941, functioned, in addition to propaganda, as a medium of instruction. As a segment reads:

The establishment of the Film Unit is another progressive step which is in line with the South African policy of building a modern army in the quickest and most efficient manner. The use and value of films [and newsreels] in the sphere of training is so well known that this aspect need hardly be mentioned...At present, nearly forty units have installed projectors. During the day they are used for instruction, and in the evening their use is equally valuable for entertainment.

Underlying this, there also lurked a growing mindfulness of the fact that propaganda had to convey a wide variety of messages if it was to be most effective - especially in the increasingly complex state of affairs 
during the final stages of the war. Thus, the Union continued to advocate that the country's entry into the war was not without merit, and that the government needed the full support of her men and women in order to launch a successful war effort. And the African Mirror newsreels emphasised that in spite of everything, many aspects of the traditional Afrikaner way of life were surviving during the war years, but the government stressed that for this to continue to be the case all South Africans had to rally behind the war effort. The major contributions, of especially Afrikaner women and other workers, to the war industries and auxiliary forces were given regular public recognition - dramatic images of advanced military technology also provided re-assurance as to the Union's fundamental military growth and capabilities of protecting its own (Reeves, 1983:470).

As the war intensified and South Africa's participation grew, the African Mirror newsreels had to reassess their aims and goals in order to sustain the interest and motivation of their South African audiences. This was partly due to the fact that the weekly newsreels and the messages and footage it contained were becoming too repetitive.

The weekly African Mirror newsreels and radio propaganda programmes like those of Nigel Sutherland were broadcast by the South African Broadcasting Corporation in an effort to encourage people to join the armed forces, whilst also giving detailed accounts of the accomplishments of those South African troops already on the battlefields. The "Commando on Wheels", a mobile recruitment unit under the direction of Colonel Werdmuller, the "War Train" and various other mobile units, visited major centres to mount air shows, armoured vehicle manoeuvres and artillery demonstrations (Keene, 1995:19).

Consequently, the propagandists soon realised that in order to keep the vigour for the Union's war effort alive the country's propaganda campaign had to start taking the economic, social and political climate of the times into consideration, and that they had to adapt their campaigns and newsreels accordingly. Chetty noted that other than patriotism, a feeling of heroism was also evoked through these newsreels and short films. Figures in uniform were regularly seen appearing on hilltops waving flags or steadily trudging through enemy fire - never wavering from the ultimate aim of victory (2001:69).

\section{Conclusion}

Chetty notes that along with the idea of "justification of war" by the countries involved in "fighting for freedom", comes the equally powerful rhetoric of "defending the homeland" (2006:194). The enemy is portrayed in an antagonistic manner as the aggressor, whereas the local soldier is depicted as the righteous defender of women and children, and of the vital interests of the home country. In addition to this, the romanticized version of a soldier is one of someone who is expected to take no pleasure in killing - and it is considered an appalling but necessary task to kill in order to save a wounded comrade, a battalion under siege or civilians in the line of fire. War becomes a decent cause:

This was particularly the case on the part of the Allies of the Second World War where the presence of a clearly defined aggressor in the form of Hitler and the threat he presented with his quest for lebensraum (or, for the Americans, the Japanese attack on Pearl Harbour) created a justification for a "noble war" - a desire to rid the world of the evils of fascism (Chetty, 2006:195).

Many commentators have labelled the Second World War as the battle of persuasion - as both warring sides expanded and pursued all available forms of communication, and in its intention at least, propaganda came to be seen as serving more than one function in the gigantic "battle of persuasion" (Cull \& Cullbert et al., 2003:441-442). On the one hand, it was used to inspire and to invigorate populations - to serve the need to raise collective morale. On the other hand, it was directed at making war efforts more energetic and more efficient, at conserving vital resources, and at increasing public war donations and voluntary involvement in war productions and industries (Hodson, 2011:i). This propaganda scope also encompassed the Union government's motivations in exploiting the African Mirror newsreels as a major weapon of popular wartime communication. The weekly circulation and screening of an array of images - ranging from troops in training, General Smuts addressing troops at the frontline and training camps, and women hard at work in the munitions factories - succeeded in keeping the Union's war effort alive in the hearts and minds of its citizens. 


\section{Part 2: Recruitment, Mobilisation and Demobilisation Films}

\section{Introduction}

The films that will be discussed in this section will be divided into categories correlating to the phases of the war. The first two, Fall In and Delivery on Due Date, are good examples of films produced during the recruiting and military industrialization phases of the war effort. The third and fourth films, She is South Africa and War Workers, depict the vital role that wartime industry workers, in particular women, played during the war effort. And then lastly, Planning for Peace, aimed at making the government's demobilization efforts public and to reassure South African hearts that their war service and sacrifices would not be forgotten after the war ended.

Even though some of the visual media broadcast in South Africa during the war also served an entertainment purpose, the focus of this study will mainly fall upon the influence of propagandistic media on the psyche of Afrikaner communities, which represented a white citizenry in need of pro-war mobilisation. Attention will also be paid to how it affected other groups in South Africa at the time.

Jowett and O'Donnell contend that communication can be defined as a "process of exchange in which sender and receiver, either through mediated or non-mediated means, create, acquire, transmit and use information. When the information is used to accomplish a purpose of sharing, explaining, or instructing, this is considered to be informative communication" (Jowett\&O'Donnell, 1999:25). In general, informative communication is considered too neutral as it is characterized by a very specific and to-the-point-language, and this informative discourse, according to Jowett and O'Donnell, has by its nature achieved a "privileged status of being beyond dispute" (1999:26).

The ability of film to strike some sort of empathetic chord with its audience and to provoke an emotional reaction makes it a valuable means of wartime propaganda. For a piece of state propaganda to be judged effective, eliciting the emotional and perhaps unquestioning response required, the state's propagandists needed to consider both the informative and persuasive aspects. This perspective has to be taken into account by the South African company, Union Film Productions. This company produced both English and Afrikaans propaganda films for state agencies such as the Union Defence Force (UDF) Film Unit and the Bureau of Information. Prior to the outbreak of the war, in line with their collaboration with these abovementioned agencies, both companies produced films that reinforced the government's official policies on race. In particular, these concerned the African Reserves as well as those laying emphasis on the ideal of an Anglo-Afrikaner white South Africanism, a spirit of understanding and acceptance between the English and Afrikaans-speaking white communities in South Africa.

The state-authorized films produced during the war provided a means of determining the particular ideal "identity-types" of people participating in the respective military and auxiliary branches of the UDF that were advocated by the state. The Director of Military Intelligence, E.G. Malherbe, was clear in his views on the role that film was expected to play as an instrument of war. In 1940, during a speech delivered to the Union Unity Truth Service, Malherbe unequivocally stated that he believed film could embody an extreme value with regards to state propaganda and persuasion during times of war. For Malherbe's intelligent grasp, it was the "semblance of truth" which was a fundamental feature of film as well as its representation of "direct reality" which it purported to show, which made it a prime instrument in "concealing propaganda" (Chetty, 2006:56).

Propaganda that is informative combines the need to be "realistically" informed, evident in the war-time success of newsreels, with the underlying promotion of a specific ideology which is directed at a specific audience. And, in turn, persuasion also addresses the needs and concerns of its target audience in order not to alienate viewers. It then becomes clear that propaganda could not simply be imposed from above. It has to be directed at a specific audience in striking pre-existing chords, whether nationalistic, emotional and psychological with that audience in order to be most effective and influential. Both the potential and the limitation of such forms of propaganda to a large extent, therefore, mirrored identifiable aspects of South African society. These informed documentary and fictional short films, as well as the African Mirror newsreels which played a significant role in the propagandists' efforts.

The short films produced by the UDF and other entities during the war were aimed at exhibiting the level 
of the Union's preparedness for the war it was entering. Looking at the army, the navy and at munitionsmaking, these productions were to a great extent filled with factual images which were left to speak for themselves (Reeves, 1983: 466). Here, the crucial contributions made by the Union's women in wartime factories and in other industries were given public recognition. Audiences were also given reassurance of the strength of the Union's war campaigns by highlighting advanced military technology, for example, at recruitment parades.

These films, along with others of the early 1940s, can in some respects be recognized as a central component in the growth and development of South African national cinema. The present concern, though, is on determining the ways in which these shorts may have been received and understood by audiences during the war.

South African films produced for wartime purposes were usually divided into discrete sections where a particular theme of event was emphasized. The four films that will be explored will be based on these respective sections of wartime representation. These films heralded a combination of actual footage taken from the front lines, with voice overs describing the scenes, thereby taking on a similar form to that of the official newsreels that were familiar to cinema audiences.

\section{Recruitment, mobilisation and demobilisation Campaigns: The Union's Short Films}

Reeves argues that there was a trend visible in the earlier "films of the war outside Europe [which] offered exotic images of the unfamiliar; [and that] the official newsreel [screened during World War Two] presented a more and more varied diet as time went on" (Reeves, 1983:470). Films produced and screened during the early years of the war held a more escapist and entertaining stance within those communities caught in the grip of the conflict, but as the battlegrounds expanded the aim and intent of films were also re-routed to fit into the war campaigns of partaking countries. These entertainment films thus gave way to more factual films which brought took the use of propaganda to new levels, and ensured that a more extensive range of material was covered.

The films themselves fell into different groups ranging from those containing footage of the war itself and the activity on the front lines to more educational films showing the kind of work carried out by various divisions of military duty and service. Films depicting work and industry on the home front in aid of the war effort, especially the role of women, also figured centrally as part of the Union's propaganda campaigns.

The first of the films, Fall In (Part 1 \& 2), has also been examined in another study by Chetty. Narrated by Major-General George Brink, it was produced by Union Films and displayed images of Brink as a powerful, authoritative figure counter-posed against images of fascists and supporting troops going "Up North" to fight in the Union's expeditionary campaigns.

In reaction to the disastrous outcome of the siege of Tobruk, the film Fall In evoked Major-General George Brink's Call to South Africa, calling on all South Africans to "throw their weight behind the war effort" (Chetty, 2006:60). This call came at a crucial point in the war campaign as the garrison defeat was viewed as a difficult turning point in South African support for the war. In constructing its messages, a number of key leitmotifs were visible in Fall In. These, regarding the appeals of patriotism, national duty and honour, were conveyed vigorously to the Union's population at this crucial stage in the war. In the film, Major-General Brink referred to General Smuts, who had advocated the Union's entry into the war, as one of the world's strategists (1940, Fall In, Union Film Production:FA19).

This, along with acknowledgment of Smuts' role as a republican Boer General in the South African War, where he had so commendably battled with the British for independence, acted as a subtle reminder of his particular service during the Second World War to the well-being and security of the Afrikaner people. Significantly, this came at a point when Smuts was finding himself still at odds with discontented Afrikaner nationalists and other radical anti-war groups who had been strongly opposed to South Africa's entry into the war from the very outset.

Thus, the film suggested, as wartime Prime Minister, Smuts' primary duty was not so much caring for relations with the British government and for the welfare of the British people, but rather with the national needs of South Africa, of her citizens in general and with the position of Afrikaners particularly in mind. Brink emphasized that "General Smuts [was] always active in the best interests of South Africa" - and at this 
point in the film, the narration was accompanied by images of Smuts greeting and saluting departing troops during a marching-out parade (1940, Fall In, Union Film Production:FA19). The general impression of the film was not one of Smuts' loyalty to the British Empire, but one that showed that his actions and decisions were for the sake of his country. (Chetty, 2006:61). The use of images of intensive military operations, planned industrial development, and the sending of troops to defend the country's borders, made this a very palpable symbol of national interests.

As a central feature of official propaganda in general, and specifically in terms of the Union, there existed the need to counter anti-war sentiments to hamper the effectiveness of the war effort. Consequently, according to Malherbe's wartime brief, propaganda had to take every necessary precaution and effort in order not to isolate the Afrikaner segment of the South African population.

This was evident in the frequent references to Smuts as "Oom Jannie", which appealed to South African audiences in a similar manner as when his wife, Izzy, was referred to as "Ouma", the expression of the Afrikaner-volksmoeder. E.G. Malherbe also expressed his desire that Afrikaans should be used in these films, particularly when Smuts appeared on screen, in order to explicitly associate the Prime Minister with an Afrikaner history and cultural identity.

Unsurprisingly, footage showed only white South African troops in largely combat roles, and gave no recognition to all the African, Indian and Coloured volunteers who had signed up for duties in non-combatant spheres and in other auxiliary industries. To try to put to rest civilian fears and anxieties about men on the front line and to encourage white men in particular to volunteer for combat duties, the war was in many ways "disinfected" of negative and worrying associations.

Images of troops in combat were inevitably portrayed from one angle, showing soldiers shooting at an unseen enemy, courageously charging ahead through smoke and ultimately emerging victorious. Distressing scenes of death, injury and other wartime hardships such as exhaustion, poor hygiene, and food shortage, were excluded from this film. Instead, images of white South African troops marching and traversing sand dunes as well as of troops smiling at the camera were shown to boost the morale of audiences and generate a positive attitude towards the Union's government and its military operations.

Consequently, Fall In concentrated on the threats to and the defence of South Africa's borders, which were seen also as the sole motivation and driving force behind the Union's recruitment efforts. In the film, the victories that South Africa enjoyed on its military campaigns were put on screen and sold to the public as bringing home a new-found glory to South Africa. Along with the use of other heroic images, Fall In drew on the imaginative possibility of an inherited sense of a proud past. This was used both as an appeal to memories of Afrikaner national patriotism as experienced during the Second Anglo-Boer War, as well as a call to the audience to throw their support behind the war effort.

The second film to be considered is Delivery on Due Date which was produced by Union Films in the early war years. It depicted carefully edited scenes of women auxiliary workers, steel production yards and care packages being assembled for frontline soldiers. In one scene the Director General of Supplies, Dr. van der Bijl, commends the war workers who were doing their bit for the war effort. Civilians who had their own businesses and private enterprises were also portrayed as setting aside their own interests and businesses in order to help the war effort in terms of aiding the Union's fighting soldiers.

In doing this, it depicted these workers as home front heroes hard at work - serving to meet a noble goal and maintaining an important role in aiding both distant soldiers and those who stayed behind. Once again, scenes of hard and often dangerous industrial work under arduous circumstances were avoided. Instead, the positive narration of Dr. van der Bijl was reinforced by portrayals of smiling and joking war workers in various factories. In a similar manner, the Oorlogspiere (Sinews of War, African Film Productions 1941) illustrated how all industries in South Africa were expanded and used to equip the Union's forces during the war. The effect of such depictions was that it held out the prospect of encouraging more volunteers to join the war effort and to serve their patriotic duty on the home front. After this opening phase of the war, the focus of propaganda shifted to the mobilization of more women as the recruitment of both Afrikaner and black males continued to increase.

The period between 1941 and 1945 was marked by major recruitment campaigns aimed at women. This 
required the close cooperation of media, particularly women's magazines (Yesil, 2004:107). Here, Afrikaans magazines such as Huisgenoot played an influential role. Similarly, short films such as She is South Africa; She Serves Abroad, and She Helps to Heal were particularly effective in propagating women's support for the Union's war effort.

There was also strong encouragement of other media forms such as local magazines to make their readers aware of their "patriotic duty" and "effectively" to educate millions of women to join the labour force. She is South Africa (Part 1 \& 2) showed footage of uniformed women in the Women's Auxiliary Army Services (WAAS) learning food preparation to aid injured soldiers, with the ultimate aim of becoming skilled at good nutrition. The point of this "educational" construction was to portray their national duty as being on a par with that which they provided in their homes and communities.

According to Chetty's analysis of the film She Helps to Heal:

Once it had been established that their war work was of a temporary nature, and all the skills they had learned would only be of use to them in the home or in the less threatening field of working in social or community service, the film returned to the valorization of the role of these women, '[s] he is proud to know that her contribution to the war effort is vital, important and so we salute a service which is playing its part in the bettering of South Africa' (Chetty, 2006:73).

Similar to the stance of other Allied countries - and to that of some of the Axis countries as well - the Union realized that propaganda had to be used to try to alter or shift notions of the "proper" role for women as wives and mothers in order to convince females to work in war industry and in the auxiliary services. As part of full mobilization efforts, the government, and more specifically those heading the Union's propaganda campaigns, urged magazines to make women their central focus and show women doing the sort of work not fully respected and appreciated as war work. This included the hard, strenuous, unglamorous work of women in agriculture, communications, education, medical care, restaurants, hotels, stores, transportation, and at the office.

Equally, rendering women's participation in war industries as a mere extension of their stereotypical roles made it easier for propagandists to change their messages when the war was coming to a close: women should return to their homes to help rebuild the country domestically and provide nurturing support for returning soldiers. Yet, women of the time were not so easily influenced and manipulated, particularly during the middle years of the war which were marked by a drop in female enlistment numbers. Consequently, propaganda had to add an adventurous element in order to enhance its appeal to attract women to join the war effort (Chetty, 2006: 53). By the end of the war, though, the key roles of white men and their greater armed sacrifice, once again took centre stage.

As the medium of film became more easily accessible by civilians on the home front, there were short films which depicted in a remarkable and un-patronizing manner the contribution of the Women's Auxiliary Services. This was done by using vivid actuality photography in numerous locations such as munitions and supply factories, to emphasize the great variety of tasks performed by these "quiet, unspectacular women doing unspectacular jobs" (Spicer, 2003:1009). In addition to the latter, another tactic was to continuously comfort and reassure women and put their minds at ease that their femininity would not be "ruined" should they take up an unglamorous war job in a wartime industry.

The fourth film War Workers, produced by Francis Coley, also focuses on the Union's war effort behind the front lines. It portrays the military war workers, both men and women, in the munitions factories as well as in varied roles as engineers, miners and moulders. All of these volunteer men and women are depicted in a valiant manner to show their patriotism and how they are working to secure a safe future for South Africa. Just as the frontline battles brought home the reality of the war, another important element that was highlighted by this film is that men and women are depicted as working equals - both playing a crucial role in supporting the war effort.

In War Workers, as in the case of She is South Africa, one gets the sense that the Union's war propagandists aimed to use and to extend the notion of volksmoeder, which was inherent to Afrikaner culture, into a social sphere broader than just the home. As war workers, the women became volksmoeders on a national level not only bearing and raising children, but also as caregivers and supporters of all soldiers (and their families) 
caught up in the war. Workers are depicted as happy and satisfied with the contribution that they are making - however small it may seem to viewers. The underlying message of this film was that no effort or contribution was too small or insignificant. In mobilizing extra support for the Union's war effort, every task, however, minor, was represented as being urgent and of value.

The fifth and final film to be considered is the 1944 Planning for Peace, which was produced by the Bureau of Information for the Directorate of Demobilization (DOD). It deals with the post-war prospects and occupational opportunities for returning white servicemen. While advocating the demobilization ideals outlined by Smuts to the British Parliament, Planning for Peace has a very notable focus. Completely partial, it was aimed solely at white servicemen. During the entire film, no mention was made of or acknowledgment given to the contribution of black men to the war or of any measures that were to be taken in order to assimilate them back into society after the war ended (Chetty, 2006:73). Many returning ex-servicemen harboured great anxieties about their status in a post-war South Africa. As a result, films like Planning for Peace was produced and screened in order to stress the fact that the Directorate of Demobilization would be responsible for the aptitude testing of ex-servicemen to place them in suitable jobs after returning from the front lines. Training facilities in the form of vocational institutions and specialized educational institutions were also to be set up to enable discharged men to acquire skills for future employment - these plans included provision for disabled soldiers.

\section{Implication for, and effects on, the South African Public}

When considering the implications and effects of the 1939-1945 war on the South African public, one has to take into account the way in which Afrikaner participants handled their war experience in cultural and political terms. Albert Grundlingh observed that "the military world that the new Afrikaner recruit entered, was predominantly British [and] the defeat of the Boer forces during the Second Anglo-Boer War in 1902 at the hands of the British meant that as far as South African defence organization was concerned, republican military traditions and structures were to be replaced by those of the British" (Grundlingh, 1999:363). Thus, it was almost inevitable for the Union's leadership, especially those in military command, to be inclined to lean towards British habits and procedures in order to give substance to the country's fighting establishment.

Bearing this in mind raises the issue of the way and the extent to which ordinary South Africans were affected by images and other messages of the war conveyed through the media. In the Union, as in other combatant countries, manipulative official films were widely used - both in order to keep audiences informed and to try to mould sentiment by crafting a rationale for war. Accordingly, when one looks at the messages reflected by the Union's propaganda broadcasts, these clearly show attempts by the Smuts government to create and exploit this rationale. For the country's white citizenry, this was undertaken by underscoring ideas of bonding, national unity and a collective memory shared by especially white Afrikaners after the end of the Second Anglo-Boer War in 1902.

Tom Berger describes collective memory as not being based in or on the personal experiences of individuals or even groups of individuals in any given society, but argues rather that the "memories of the collectivity" as a whole serve a practical function. In his words:

They provide a collectivity with an identity and a common myth of origin. They endow it with emotional and normative underpinning [and collective memories]...simplify the task of organizing collective action by providing members with a common language and a set of understandings about past, current and future situation (Berger, 2002:80).

Thus, when Smuts declared war against Germany, it was soon realized that to bridge the political divide within white communities, the Union's propaganda campaigns, especially visual and cinematic ones, had to bring notions of a collective Afrikaner identity into play once again. In practice, certain "common codes" invite people (viewers, listeners and readers) to consider and regard themselves as part of a given community, or in terms of the Union between 1939-1945, as part of a national struggle to safeguard South Africa.

Hall argues that it is fundamental to acknowledge and consider the degree to which "one can project oneself into the images so that one can place oneself within the field of what is being (re)presented to you" (2006:17). As he stresses, "it is not that the image has a meaning. It is, as it were, in the relations of looking at the image, which the image constructs for us, that that meaning is completed" (Hall, 1997:16-17). Images can 
potentially have an extensive range of meanings, but the meaning that a spectator denotes depends on the level of engagement - emotional, social, psychic, or imaginary, with what the image is ultimately aiming at saying or doing.

In terms of the Union's propaganda campaigns, all "advertising" works and publications were attempt at winning over the hearts and minds of South Africans from all walks of life by lobbying for a common sense and feeling of national identification. And, when considering the cause and effects of the Union government's wartime propaganda, one soon comes to appreciate Stuart Hall's point that the viewer is unavoidably implicated in the production of meaning through the image.

Films, like air shows, were still a relative novelty in the rural areas, but it would appear that their reformulation of Afrikaner history was done proficiently enough to resonate with a war loyalist core of Afrikaansspeakers (Grundlingh, 1999:357). Grundlingh goes further by arguing that it certainly raised concerns in the nationalist Afrikaner press, with readers being warned against the way in which Afrikaner history was being distorted in emotional ways to serve the war aims of the Smuts-government (1999:358).

\section{Conclusion}

If the role of film during the Second World War was chiefly to promote nation building for war, then the Union's propaganda films perhaps worked mainly in two ways. Firstly, it was to try to allay fears regarding the injurious effect of war on its key frontal participants - white male combatants - by circulating positive claims of war achievements and the war campaigns in general. These representations also tried to avert the volunteer service reservations associated with protecting national cause and national honour in the face of the demands and disruptions produced by war. This was attempted by making sure that wartime films contained and advocated a strong conservatism regarding the subsidiary roles of both white women and black men.

Thus, films served to confirm the subordinate status of men who had enlisted in the Non-European Army Services (NEAS) as labouring auxiliaries to make up for the departure of white men to armed duties. A similar characterization applied to films depicting the service role of white women, with these containing the added feature of emphasizing the temporality of their work in the auxiliary services. This also served to confirm their social place in a post-1945 domestic sphere in South Africa - for even in official propaganda films, the notion of the "united nation" has its limits. In their highly partial dedication of footage to the role of a volunteer white population, "films gave short shrift to the role of black men, [and this] introduced a discordant note to the ideal of the all-encompassing nation" (Chetty, 2006:79).

During hostilities, the home front institution of national cinemas was more than a popular form of mass entertainment. As well as providing a world that could be escaped to, films also acted as vital agents of information which carried with them the important role of shaping (and re-shaping) the (world) views of audiences in belligerent countries. Films act on emotions and consequently wartime films helped to give shape and form to a mass persuasion-weapon used in a kind of moral crusade, carrying the rightness of a national cause. Due to the popularity of film during the war years, it soon became an increasingly important asset of propagandists. Its dual role as an agent of "popular" persuasion and entertainment helped to ensure that its informative counterparts, newsreels and documentaries, not only explained and justified the war efforts of countries such as South Africa, they also helped to determine the ways in which, and the extent that the war contribution would be remembered (Paris, 2007:2).

It has been argued that the Second World War highlighted and underscored the Union's contradictory political position - for "inherent in the appeals made by propaganda to feelings of nationalism and the hegemonic roles of men and women, were contradictions based largely on the contrast between the fight for freedom and democracy which was how the Second World War was portrayed on the part of the Allies, and the lack of freedom domestically" (Chetty, 2001:50). Despite the fact that appeals were made to patriotism and nationhood, South Africa was not a united nation in any way. Rather, the recruitment and mobilization for the war highlighted fragmentation within South African society over race, ethnicity and gender. Many of the people mobilized were in fact not considered citizens.

When studying the various newsreels and short films produced by the Union Film Unit during the war, it becomes clear that the films served as more than a mere source of information. Their representation of 
the groups involved in war work - white men, white women and black men - laid bare the attitudes that were embraced by the state regarding future prospects, especially post-war job possibilities, as well as the limitations of prospective improvement and potential for social change brought about by the war and the new experiences of war work.

The way in which these films attempted to construct an "imagined" nation and, in particular, the silences and omissions evident in that construction of a Union nation under arms, is a crucial part of any consideration of the meaning of South Africa's 1939-1945 war strategy. Equally, Yelis' general argument is of relevance to this case study. Wartime films often functioned to "transform" government "information messages" into high-powered propaganda during times of severe political and military pressure and difficulty. This can also apply to the nature of the Union's propaganda films. These films, such as Fall In, Servant of a Nation, Delivery on Due Date and She is South Africa, were skilfully thought out and designed to try to inculcate the proper attitudes and behaviour under the Union's war conditions, and consequently to encourage voluntary enlistment for war service, to help sell war bonds and to build morale among a mobilized population. In Planning for Peace, the focus turned to the demobilization of returning soldiers and the re-entry of both men and women back into South African society. This was accompanied by hopes of an improved post-war South Africa, something that was portrayed in propaganda campaigns and reflected in the reality faced by returning UDF servicemen and women.

In closing, it might be reasonably said that today, more than half a century after the war's end, the memories of those strained and turbulent years are steadily receding. It has been the hopeful aim of this two-part article to record the Union's national war effort by examining the government's mobilization and propaganda efforts through imaginative means. Thus, by exploring the visual footage of recruitment campaigns, training exercises, home front services, and documentary representation of the battlefields, this article has attempted to evaluate the selling of the war effort and the mobilization of consent by the Union of South Africa authorities. One may, hopefully, emerge with a deeper sense of appreciation for such media depictions during times of conflict, and understand better their far-reaching influence on society.

\section{References}

Berger, T. (2002) "The Power of Memory and Memories of Power: the cultural parameters of German foreign policy-making since 1945", in Muller ed.: Memory and Power in Post-War Europe (Cambridge: Cambridge University Press), pp. 76-99.

Butcher, E. (2002) 'To what extent are the labels of 'propaganda' and 'art' appropriate in the description of Leni Riefenstahl's Triumph des Willens (1935)?" (Manchester: Honours Degree in French and German Studies, University of Manchester).

Bruzzi, S. (2006) New Documentary - A Critical Introduction (New York: Routledge).

Chapman, J. (1995) "Official British Film Propaganda during the Second World War" (Lancaster: PhD Thesis, Lancaster University, 1995).

Chetty, S. (2001) "Gender under Fire - Interrogating War in South Africa, 1939-1945" (Durban: MA Degree Thesis in the Program of Historical Studies, University of Natal).

Chetty, S. (2006) "Our Victory Was Our Defeat": Race, Gender and Liberalism in the Union Defence Force, 1939 - 1945" (Durban: PhD Thesis in the Program of Historical Studies, University of KwaZulu-Natal).

Cull, N. J \& Culbert, D. et al. (2003) Propaganda and Mass Persuasion. A Historical Encyclopedia, 1500 to the Present (California: ABC CLIO).

Doherty, M. A. (2000) Nazi Wireless Propaganda - Lord Haw-Haw and British Public Opinion in the Second World War (Edinburgh: Edinburgh University Press Ltd).

Grundlingh, A. M. (1999) "The King's Afrikaners? Enlistment and Ethnic Identity in the Union of South Africa's Defence Force during the Second World War, 1939-45", The Journal of African History, 40, 3, pp. 351-365. 
Hall, S. (1997) "Representation and the Media", Media Education Foundation - Transcript (Northampton: The Open University).

Hodson, B. (2010) The Propaganda War: Axis and Ally Persuasion in WWII, http://www.suite101.com/content/thepropaganda-war-axis-and-ally-persuasion-in-wwii-a244065\#ixzz1FLfWlEYL (Accessed 01 March 2011.)

Jowett, G. S. \& O’Donnell, V. (1999) Propaganda and Persuasion. $3^{\text {rd }}$ Ed (California: Sage Publications).

Keene, J. ed. (1995) South Africa in World War II (Cape Town: Human \& Rousseau).

Paris, M ed. (2007) Re-picturing the Second World War - Representations in Film and Television (New York: Palgrave MacMillan).

Reeves, N. (1983) "Film Propaganda and Its Audience: The Example of Britain's Official Films during the First World War", Journal of Contemporary History, 18, 3, pp. 463-494.

Schechter, D. (2004) "Selling the Iraq War. The Media Management Strategies that We Never Saw" in Kamalipour, Y. R \& Snow, N. eds, Propaganda - A Global Perspective (Maryland: Rowman \& Littlefield Publishers, Inc.).

Slocum, J. D. ed. (2006) Hollywood and War, The Film Reader (New York: Routledge).

Sinclair, A. (1992) "South African Posters in the Second World War", Military History Journal, 9, 1, http://samilitaryhistory.org/vol091as.html (Accessed 6 July 2011).

Spicer, A. (2003) "Extending People's Minds for a Brief Time Every Day: The Wartime Propaganda Short", Journal of Media Practice, 4, 2, pp. 105-112.

Welch, D. (2001) Propaganda and the German Cinema 1933-1945 (London: I .B. Tauris Publishers).

Yesil, B. (2004) "'Who Said this is a Man's War?' Propaganda, advertising discourse and the representation of war worker women during the Second World War'", Media History, 10, 2, pp. 103-117.

. General Staff, Defence Headquarters. (10 January 1941) Military Propaganda Handbook No. 1 (Pretoria: The Government Printer).

\section{Author Information}

Anli LE ROUX is a graduate student at the University of Cape Town. Her graduate research work has focused on South African war documentary and propaganda production and the effects these films (during and after the war years) have had on the audience perception of the portrayed events. 